\title{
'Superweeds' or 'Survivors'? Framing the Problem of Glyphosate Resistant Weeds and Genetically Engineered Crops
}

\author{
Carmen Bain,* Theresa Selfa,** Tamera Dandachi,* and Sara Velardi** \\ *Department of Sociology, Iowa State University, Ames, IA, USA \\ **Department of Environmental Studies, SUNY-ESF, Syracuse, NY, USA
}

\section{Corresponding Author:}

Carmen Bain, Department of Sociology, Iowa State University, 316 East Hall, Ames, IA 50011, USA Email: cbain@iastate.edu

\section{Acknowledgements:}

This research was supported by the USDA-National Institute of Food and Agriculture (NIFA) under Grant No. 2013-68004-20374. Any opinions, findings, and conclusions expressed in this material are those of the authors and do not necessarily reflect the views of the USDA. The authors would like to express their appreciation to all those who kindly agreed to participate in this research project.

\begin{abstract}
In this paper, we explore how efforts to frame the socio-environmental problem of glyphosate resistant weeds - superweeds - at particular scales shape calls for certain governance strategies
\end{abstract}


and regulatory responses. We use a political agronomy approach and the politics of scale literature to understand the linkages and relationships between socio-political and economic forces and the problem of glyphosate resistant weeds. We draw on in-depth interview data with representatives from farm groups, consumer and environmental advocacy organizations, agriculture and biotech companies, government regulatory agencies, and agricultural extension agents, together with a content analysis of websites of GE supporters and opponents. Together these data are used to explore how the problem of superweeds is being framed by proponents and opponents of GE crops, and among agricultural scientists, advocacy organizations and business. We conclude that when environmental problems associated with pesticide resistance are 'scaled up' to incorporate more systemic agricultural issues and are linked with broader socio-economic and political issues that impact a larger public, there are greater possibilities for pushing for government intervention and regulation to address environmental burdens and externalities.

Keywords: glyphosate resistant weeds; genetically engineered (GE) crops; politics of scale; superweeds; framing

\section{Introduction}

The problem of 'superweeds' - weeds that have developed resistance to the herbicide glyphosate - has emerged as a critical new front in debates concerning the sustainability and 
governance of genetically engineered $(\mathrm{GE})^{1}$ crops and commodity agriculture. Commonly known by its trade name Roundup, glyphosate was commercialized by Monsanto in 1974 and became the primary weed management tactic among farmers with the release of glyphosateresistant, GE (Roundup Ready) soybeans, corn, and cotton in $1996{ }^{2}$ Glyphosate resistant weeds now affect hundreds of millions of acres of farmland in the US as well as in other countries that have adopted GE crops, such as Argentina and Brazil. By 2014, glyphosate resistance had cost US farmers around \$1 billion in lost crops (Koba 2014). Proponents of GE crops had been able to maintain support by arguing that GE crops are good for the environment because they promote soil conservation and good for the farmers that grow them. Both arguments are now being challenged with the spread of glyphosate resistant weeds. In addition, following the classification of glyphosate as 'probably carcinogenic' to humans in 2015 by the International Agency for Research on Cancer (IARC), the use of this herbicide has become increasingly controversial and has led to environmental and consumer health campaigns (Bonny, 2016).

In response to glyphosate resistance, farmers are applying more herbicides including those that are more toxic than glyphosate, and using less environmentally benign on-farm practices, such as tillage (Benbrook 2012). Biotech companies, such as Dow AgroSciences and Monsanto, are commercializing new crops engineered to tolerate 2,4-D and dicamba, older herbicides that

\footnotetext{
${ }^{1}$ GE plants are those where recombinant DNA (rDNA) technology has been used to insert a gene from any species that has a desirable trait, such as resistance to a specific virus, or herbicide or insect tolerance. This desired trait is then expressed in the genetically engineered plant.

${ }^{2}$ Roundup and glyphosate are often used synonymously since glyphosate is the active ingredient in Roundup. However, it is important to note that Roundup also includes adjuvants, which are chemicals added to improve the performance of the active ingredient, in this case, glyphosate. Adjuvants are not regulated by the EPA and concerns have been raised about their role in increasing Roundup's toxicity (see Bonn, 2005; Cox and Surgan, 2006). This debate may become more pertinent as industry efforts to develop adjuvants to address glyphosate resistance increase (see Johnson et.al, 2015).
} 
are considered more toxic to human health and the environment than glyphosate. Glyphosate resistance then poses significant social and environmental concerns regarding the health, wellbeing and sustainability of our agrifood system and natural environment.

Social scientists have begun to examine the social significance of these issues, although much of the research has focused on farmer perceptions and attitudes about herbicide resistance in GE agriculture (Binimelis et.al, 2009, Dentzman et al 2016; Fischer et al 2015; Erwin and Jussaume, 2015; Bonny, 2016). Our paper contributes to this emerging literature by employing a political agronomy approach (Sumberg et.al, 2013) to examine the relationships between sociopolitical and economic forces and the problem of glyphosate resistant weeds. In this paper, we address the following questions: What social, political and economic forces led to the problem of glyphosate resistant weeds? How is the solution to this problem of resistant weeds being framed and by whom? How do particular "framings and narratives" (Sumberg et al, 2013: 2) shape governance options for new agricultural biotechnologies?

To answer these questions, we draw on data from in-depth interviews with 29 key informants from environmental advocacy organizations, agricultural scientists and extension agents, farm organizations, and agricultural and biotech companies. In addition, we conducted a content analysis of websites of the key organizations involved in the GE debate in the US. Together these data are used to examine how the problem of superweeds is being framed by proponents and opponents of GE crops, and by agricultural scientists, advocacy and business organizations. We explore how efforts to frame the socio-environmental problem of glyphosate resistant weeds at particular scales lead to particular governance strategies and regulatory responses. We argue that both proponents and opponents of GE crops use discourses of 
neoliberalism and scale as a way to assign responsibility and frame the problem of glyphosate resistance in a manner that either rationalizes or rejects regulatory intervention.

Proponents of GE crops naturalize the problem of glyphosate resistance, arguing that weed resistance occurs regularly in nature and is part of the agricultural production system, which needs to be distinguished from the advent of GE crops. They also scale down responsibility for glyphosate resistance, focusing on individual farmer behavior as primarily responsible for the problem (Harrison, 2006; Kurtz, 2003; van Lieshout et.al, 2014). In contrast, critics of GE crops are attempting to frame glyphosate resistance as a structural and systemic problem where weed resistance is a product of the input-intensive, monocultural agricultural system. While they recognize that farmers readily embraced glyphosate and came to rely exclusively on the chemical at the expense of a diversity of weed management practices, they argue that in the context of commodity agriculture and the transgene-facilitated herbicide treadmill (McAfee, 2003), farmers had few alternatives. In their efforts to scale up the problem and frame it as systemic, critics of GE crops attempt to gain traction for greater political oversight and regulation of GE crops and agricultural chemicals.

In the next section, we describe the methods used to gather and analyze our data. This is followed by a background discussion to situate the emergence and expansion of glyphosate resistant weeds in the US, and the regulatory framework that exists to manage GE crops in the US. Following that, we describe the theoretical framework that guides our analysis of interview and content analysis data. Drawing on our data, we illustrate how scaled discourses are used both by GE proponents and opponents to frame the problem of glyphosate resistant weeds, and to justify the appropriate responses to the problem. In the final sections, we discuss conclusions and implications. 


\section{Methods}

We used a purposive sampling technique to identify organizational websites disseminating information about GE and the growing issue of herbicide resistance and that included both critics and supporters of GE crops. In a general web engine search we used keywords "GMOs ${ }^{3}$, "superweeds," and "GMOs and herbicide resistance" to identify organizational websites that were prominent search engine results. Websites' content on the initial pages of the search engine results were explored and the website sample was narrowed based on the following criteria: 1) the organizational mission statement and the website content included sections dedicated to the GE debate; 2) the organizational website took a specific stance on GE practices in crop production (in favor or critical of GE technology); 3) the organizations have been actively involved in the present GE debate with content related to current statewide and/or federal policies such as moratoriums on the planting of GE crops or labeling of foods produced through GE; and 4) the websites contained content specifically related to herbicide resistance and GE crops. A total of eight websites were selected for content analysis with an equal number of websites critical of and in favor of GE crops to provide a well-rounded analysis. The following websites that took a critical stance on GE crops and herbicide resistance were selected for analysis: 1) Center for Food Safety (http://www.centerforfoodsafety.org/\#); 2) Environmental Working Group (http://www.ewg.org/); 3) Food and Water Watch (http://www.foodandwaterwatch.org/); 4) Just Label it Blog (http://www.justlabelit.org/). Websites analyzed that took a positive approach to GE crops were: 1) GMO Answers (https://gmoanswers.com/); 2) Coalition for Safe Affordable Food (http://coalitionforsafeaffordablefood.org/); 3) Genetic Literacy Project

\footnotetext{
${ }^{3}$ In the public debate around labeling of GE foods the term 'genetically modified organisms' (GMO) has come to dominate the public discourse rather than genetic engineering.
} 
(https://www.geneticliteracyproject.org/); 4) Facts About GMOs.org

(https://factsaboutgmos.org/).

Websites were explored by looking through posted web pages, articles and press releases related to GM foods, the environment and/or specifically herbicide resistance. Analysis of website content was conducted in November 2014, March 2015, and September 2015, and data collected from websites spanned from 2011 and 2015. Each website was read through first to determine common topics discussed. Within these websites, the three most prominent topics were related to glyphosate and herbicide resistance, followed by a broad focus on biotechnology and its effect on the environment, and the least frequently mentioned topic was GM foods. Data were coded in terms of how the organization explained the causes of the problem of glyphosate resistant weeds, who or what was responsible, and how they framed solutions to this problem.

In addition, we conducted semi-structured interviews between July 2013 and September 2015 with 29 key informants with expertise regarding GE crops and herbicide resistance. These included individuals, such as agricultural extension agents, as well as representatives from organizations including farm groups, consumer and environmental advocacy organizations, agriculture (both organic and conventional) and biotech companies, and government regulatory agencies (see Appendix 1). The initial interview participants were sampled purposively because of their expertise and knowledge regarding GE crops, weeds, herbicide resistance, human health and environmental concerns related to herbicides and GE regulations. The remaining participants were then selected through snowball sampling. For example, we interviewed three crop and weed specialists working directly with farmers who were recommended to us because of their expertise and insights into grower perspectives on this issue. Interviews were conducted inperson or by telephone with each interview lasting approximately one hour. All interviews were 
recorded with permission of the participants, transcribed verbatim, and coded in terms of how informants explained the causes that led to the problem of glyphosate resistant weeds, who or what was responsible, and how they framed solutions to this problem.

This paper is part of a larger, on-going project investigating societal acceptance issues and concerns related to GE food and agriculture. As part of this broader project, a survey of 2,400 Midwest soybean farmers examining their perceptions and management of glyphosate resistant weeds was conducted in 2016. Initial findings from this survey will be forthcoming in 2017 as a [Name of University] Extension Report. These findings will make an important contribution to broadening our understanding of farmer perspectives regarding the problem of glyphosate weed resistance.

\section{The Political Agronomy of Glyphosate Resistant Weeds}

Over the past decade, the number and geographic spread of glyphosate resistant weeds in the US has increased dramatically. According to the USDA, glyphosate resistance exists in 14 weed species and biotypes in the US (Fernandez-Cornejo et.al, 2014). Since 2009, infestations of

glyphosate resistant weeds in the US have more than doubled and some 70 million acres of US farmland are now affected (Koba 2014; Neuman and Pollack, 2010; UCS 2013). Weed resistance has also spread to every country that has planted herbicide tolerant crops. In 2012, around 420 million acres of GE crops had been planted in 28 countries, including Brazil, Argentina, Canada, and India, and resistant weeds have been seen in all of them (Fernandez-Cornejo et.al., 2014; Service 2007). Slowing the rate of resistance and the spread of resistant weeds is viewed by many agronomists and plant scientists as one of the most critical issues facing crop producers in the US (NRC, 2010). 
Underpinning glyphosate's dominance within agriculture was the rapid adoption of GE crops (Service 2007; Nature 2015). According to prominent weed scientists, resistance to herbicides did and does occur with conventional crops. However, the commercialization of glyphosate resistant GE crops led to the "simplification of weed-control tactics" (Owen and Zelaya 2005: 301) and therefore "the selective pressure for weeds to develop resistance [was] huge" says USDA plant physiologist Stephen Duke (Service 2007: 1115; NAS, 2010).

GE crops were first commercialized in the US in 1996 and since that time have become "one of the most quickly adopted farming technologies in modern history" (Service 2007: 1114). Herbicide resistant crops are designed to survive the application of herbicides that are used to kill weeds, allowing farmers to more efficiently control pervasive weeds. By 2013, approximately half of all US cropland (169 million acres) were GE. The primary GE crops are soybeans, cotton and corn, with about 90 percent of the planted acres for these crops GE (Fernandez-Cornejo et.al, 2014). In 2013, herbicide resistant varieties accounted for 93 percent of soybean acreage, 85 percent of corn acreage, and 82 percent of cotton acreage (Fernandez-Cornejo et.al, 2014).

One of the primary reasons for the success of GE crops is their resistance to the herbicide glyphosate. Monsanto began selling glyphosate as a post-emergence, non-selective herbicide ${ }^{4}$ under the trade name Roundup in 1974 and later developed the most widespread glyphosateresistant GE variety called Roundup Ready. In the 1980s, soybean farmers relied on some 20 herbicides that used a variety of mechanisms for killing weeds but came to rely largely on glyphosate a decade later (Service 2007). Glyphosate resistant crops are simple and flexible to grow, which was an important factor in their adoption (Ervin and Jussaume, 2014). In addition,

\footnotetext{
${ }^{4}$ Post-emergent herbicides are designed to kill established and growing weeds. Non-selective means that the herbicide kills all plants/weeds that it comes into contact with except the plant that has been genetically modified to tolerate it.
} 
large scale adoption of glyphosate resistant crops was facilitated by the decrease in glyphosate prices after its patent expired in 2000 in the US, and subsequently it was produced in lower cost countries such as China (Bonny, 2016).

Bonny (2016:39) also argues that the expansion of glyphosate use in the 1990s in the US was facilitated by Monsanto scientists, who assured farmers that there was almost no risk of glyphosate-resistant weeds because of glyphosate's "unique mode of action." Monsanto scientists also promoted the simplicity, cost-savings and ease of using only one herbicide in its pamphlets and promotional materials, and encouraged farmers to use diverse formulations of glyphosate through its farmer rewards program. Since 2001, glyphosate has become the primary pesticide $^{5}$ used in the US and the number one herbicide sold in the world, accounting for $30 \%$ of the total herbicide sales worldwide in 2012 (Service 2007; Grube et al., 2011; Bonny 2016).

Efforts to eradicate glyphosate resistant weeds are leading to higher costs for farmers as well as to lower yields that are reducing profits (Fernandez-Cornejo et.al, 2014). As weed resistance grows, farmers have been forced to apply more herbicides, including those that are more toxic than glyphosate (Benbrook 2012; Fernandez-Cornejo et.al, 2014). The volume of herbicide applications has increased every year by 25 percent since the development of resistant weeds (Gillam, 2013). Farmers are also returning to more intensive management practices that they used before herbicide-resistant seeds were developed. This includes plowing fields to eradicate resistant weeds, thereby reducing the use of minimum and no till farming (Neuman and Pollack, 2010).

Regulatory Framework for GE Crops

\footnotetext{
${ }^{5}$ According to the EPA's definition of a pesticide, herbicides are considered a pesticide and both terms are used to describe herbicides.
} 
The rapid development and expansion of GE crops in the US was also shaped by overlaps in agency jurisdiction and what some perceive as a lax federal regulatory structure that relies on company data and on voluntary compliance by biotech companies. GE crops are overseen by three federal agencies as part of the Federal Coordinated Framework for the Regulation of Biotechnology. These agencies are the USDA's Animal and Plant Health Inspection Service (APHIS), the U.S. Environmental Protection Agency (EPA) and the U.S. Food and Drug Administration (FDA). The USDA is responsible for determining whether to allow the sale of seeds that have been genetically engineered. While the FDA is most concerned with the food safety of GE food, APHIS and EPA are concerned with how GE organisms affect other plants, the environment and human health.

Critics of the regulatory process have emphasized the lack of transparency and oversight and that studies for approval of GE crops commonly rely on company data rather than independent analysis and oversight (Roff, 2007). APHIS oversees the introduction of GE organisms that may pose a risk to plant health. Before the GE organism can be released into the environment, a developer must submit a permit, notification or petition for its introduction. If a developer believes that a GE organism will not pose a plant risk, a petition for deregulation of their GE organism can be submitted. Many herbicide resistant corn, soybeans and cotton varieties (including Monsanto's Roundup Ready) have achieved deregulated status from APHIS (Philpott, 2011). In August 2015, APHIS announced that it intended to deregulate corn and soybean plants resistant to herbicide 2,4-D (USDA, 2015b). APHIS is also now recommending best management practices (BMPs) for plantings of herbicide-resistant crops in order to "mitigate evolution of herbicide resistance" such as using multiple herbicide mechanisms and planting 
weed-free crop seed (APHIS, 2014). However, these are recommendations and there is no requirement for enforcement.

Under the Federal Insecticide, Fungicide, and Rodenticide Act, the EPA has the authority to determine which pesticides can be used and how they can be used. The agency is responsible for evaluating new pesticides and their proposed uses, reviewing the safety of pesticides, and enforcing pesticide regulations. Recent EPA actions surrounding the approval of new pesticides to deal with GR weeds is also telling of the relationship between federal agencies and industry. In order to have its Enlist Duo pesticide, an herbicide that combines two previously approved herbicides 2,4-D and glyphosate approved, Dow AgroSciences submitted their own scientific data to the EPA. The EPA then conducted a health risk assessment to determine the overall risks of spraying the chemical, stating that risks were minimal (EPA, 2014; Callahan, 2015). In 2014 the EPA approved the use of Enlist Duo for Arkansas, Louisiana, Mississippi, Missouri, Illinois, Indiana, Iowa, Ohio, South Dakota, Wisconsin, Kansas, Minnesota, Nebraska, Oklahoma and North Dakota. However, after continued efforts by conservation groups to block approval of Enlist Duo culminated in a legal petition challenging EPA's approval process, EPA asked the 9th U.S. Circuit Court of Appeals to vacate the agency's approval of Enlist Duo from the market in November 2015, an unprecedented reversal (Callahan, 2015). EPA stated that the synergistically toxic effects of these pesticides on vegetation had not been adequately reported by Dow before EPA approval, and concerns focused on the impacts on endangered species. EPA scientists stated they would not re-evaluate human health risks, but whether a bigger no-spray zone is needed near the edge of farm fields. In January 2016, a federal appellate judge rejected the EPA's request to overturn their previous approval, in a victory for the chemical company. In February 2016, 35 members of the US Congress sent a letter to the EPA administrator 
questioning EPA's approval process as lacking adequate consideration of environmental and public health effects. The appellate court overturned the EPA's request to vacate its earlier approval, clearing the way for Dow AgroScience's release of the pesticide for 2016 growing season (Callahan, 2016). The synergistic relationship between the federal agencies and biotech companies amounts to a regulatory process that facilitates company interests over environmental concerns.

\section{Governance of Ag-Biotech: Neoliberal and Scale Framings}

Critical scholars have argued that this lack of regulatory oversight of ag-biotechnology reflects neoliberal ideology, discourses and practices that prioritize limited state intervention and regulation of business and markets (Binimelis et.al, 2009; Kinchy et.al, 2008; Roff 2008; McCarthy and Prudham 2004; Campbell and Pedersen 2001; McAfee 2003). From a neoliberal perspective, market forces alone should determine the shape and nature of economic development (e.g. which biotech products to develop), and industry should largely manage itself (e.g. manage the human safety and environmental risks associated with products). The state should facilitate this process by promoting the development, commercialization and uptake of new biotech products, both at home and abroad, as well as by protecting business product development and profits through legal protections, such as patent laws or property rights (Roff 2008).

Kinchy et.al (2008) argue that support for minimal state regulation of ag-biotechnology has been garnered through merging the ideology of neoliberalism with the ideology of scientism. Scientism is the view that public policy should be guided by scientific facts and reasoning alone. Its strength derives from the assumption that science is value free and capable of transcending the messy world of interest-driven, value-based politics (Kleinman and Kinchy 2003; Kinchy 
et.al, 2008). Decisions regarding ag-biotech, therefore, should be based on a scientific assessment of risks, costs, and benefits, together with considerations regarding whether the decisions are economically expedient and rational (Kinchy et.al, 2008; Roff 2008). Together, neoliberal and scientism discourses are used by biotech proponents to "depoliticize ag-biotech" (Kinchy et.al, 2008: 148). That is, proponents assert that far-reaching concerns, such as the social or environmental implications of biotechnology for society, or what role the state should have in regulating the industry, are not subjects for public debate.

Neoliberalism is built around strong notions of the individual, including individual rights, responsibilities and freedoms (McCarthy and Prudham 2004), and the idea that decision-making should rest with individuals rather than the state (Binimelis, 2008). By taking responsibility for their own choices in the market, individuals are able to exercise their self-interest, thereby protecting their individual rights and liberties (Binimelis et al, 2009). The rights of individuals are closely tied to the protection and privileging of private property. In relation to agriculture, neoliberalism has created "a moral economy" (McCarthy and Prudham 2004: 277) whereby those individuals who work the land should have exclusive control of the land and the right to determine how that land is used (McCarthy and Prudham 2004; Roff 2008). From this perspective, farmers themselves should have both the power and freedom to choose whether to participate in growing GE crops and the financial benefits it can provide (Roff 2008).

In addition to drawing on the literature that highlights the role of neoliberalism in biotechnology discourse, we also employ the politics of scale literature to analyze how scale is used to frame the problem of glyphosate resistant weeds and its potential solutions (Kurtz, 2003; Harrison, 2006; van Lieshout et.al, 2014). Debates over socio-environmental problems, including how they should be defined, how they should be regulated and by whom, are often channeled 
through representations, discourses and framing related to scale (Harrison 2006). Scales can be defined as "the agricultural/spatial, temporal or administrative dimensions used to describe a phenomenon, and levels are the different locations on a scale" (van Lieshout et.al, 2014: 2). In scale framing, actors attempt to accomplish their goals and effect change by using scale frames to identify particular aspects of an issue that is of concern to them "as relevant, problematic or urgent" (van Lieshout et.al, 2014). Actors who may disagree or have conflicting goals can employ "counter-scale" framing (Kurtz, 2003: 895) to downplay the urgency, relevance, or problematicity of an issue. In using scale as a site of contestation, different actors attempt to gain an advantage through (re)framing and (re)positioning an issue (Harrison 2006). Actors strive to use scale as a way to shape public perceptions and understandings of particular issues and in doing so produce social and environmental outcomes that serve their interests and are beneficial to them (Harrison 2006).

Scale framing has important implications for governance and regulatory processes and concomitant concerns regarding power and exclusion. Social and environmental inequalities can be reinforced when actors use scale framing to obscure the nature of the problem and who bears the primary risks and costs of the problem. Actors attempt to use different scale frames to shape governance and policy alternatives including which actors, ideas, or issues should be included or excluded from consideration and the sources and sites of power and responsibility, and even regulation (Kurtz, 2003; Harrison, 2006; van Lieshout et.al, 2014). Within this context, both movements and counter-movements, activists and their opponents, attempt to situate the struggle at a scale whereby the "political opportunity structures" appear most favorable (Kurtz, 2003: 895). For example, Harrison (2006) found that representatives of regulatory agencies dismissed calls for greater oversight by "scaling down" and framing the problem of pesticide drift as 
isolated 'accidents' by individual farmers to justify a minimal regulatory response" (Harrison 2006: 513). In contrast, activists engaged in "scaling up" pesticide drift by highlighting it was a systemic and regularly occurring problem, rather than a localized infrequent accident. Activists also strategically reframed the problem of pesticide drift as air pollution which expanded the affected population beyond farmworkers to a broader public and thereby triggered the need for regulatory oversight. In the sections below, we illustrate with our data how proponents and opponents of GEs use scale framing and neoliberal discourse to discuss the problem of glyphosate resistant weeds, responsibility for the problem, and how to address it.

\section{Naturalizing Weed Resistance and Scaling Down the Problem}

The media has adopted and helped popularize the moniker "superweeds" in their reporting on the spread of glyphosate resistant weeds. ${ }^{6}$ In 2009, the Journal Star of Peoria, Illinois published an article "Attack of the Superweeds," which reported on the struggles by farmers to deal with herbicide resistant weeds. Proponents of GE crops typically reject this framing, arguing that the term superweeds is scientifically misleading and inaccurate when talking about herbicide resistant weeds. Dow AgroSciences spokesperson Jane Stautz writes on the website GMO Answers: "Weeds really aren't all that 'super.' What they are, are survivors." Similarly, the Genetic Literacy Project quoting weed scientist Andrew Kniss, stated that these weeds are not super at all and are no different from any other weeds that had developed resistance in the past (Brazeau, 2014).

\footnotetext{
${ }^{6}$ See for example: “'Superweeds' Sprout Farmland Controversy over GMOs” (Koba, 2014 NBC News);

“'Superweeds' emerge to challenge farmers" (Meersman, 2014, Star Tribune); "'Superweeds"” choke farms" (Eller, 2014, Des Moines Register); “Herbicide-Resistant 'Super Weeds' Increasingly Plaguing Farmers” (Koebler, 2012, US News); "The Rise of the 'Super Weed' Around the World" (Molla 2014, Wall Street Journal); "Superweeds Are Winning The Battle Against Farmers" (Dodrill, 2015, Inquisitr); "EPA takes on superweeds: New restrictions target Monsanto's Roundup herbicide" (Abrams, 2015, Salon).
} 
In rejecting the term superweeds, proponents of GE seek to minimize what is new or different about the phenomena of glyphosate resistant weeds, preferring instead to frame the problem as natural: a routine, biological occurrence. GE proponents seek to downplay any relationship between glyphosate resistant weeds and GE crops or monocultural agriculture, arguing instead that resistant weeds are an inherent problem that has always faced agriculture. As an interviewee from a farm organization explained:

[Glyphosate resistant weeds] are a weed that has developed some resistance through natural selection like weeds have done for centuries and centuries. So this isn't new. Like with Atrazine, weeds have developed resistance to Atrazine. Some weeds have developed resistance to glyphosate now (Andrew, Director Production Systems (GMO 101)).

Since the dawn of life on Earth, organisms have developed resistance to deleterious compounds they were exposed to... as throughout the history of life on Earth, the weeds evolved resistance to the herbicide they were exposed to (Robert Wagner, 2015, Coalition for Safe \& Affordable Food).

Proponents of GE crops recognize and are concerned that glyphosate resistant weeds pose a serious problem to farmers. However, in explaining the rise and spread of these weeds, proponents of GE tend to scale down responsibility for the problem to individual farmers. That is, glyphosate resistant weeds developed because farmers "misused" the technology, used it "over and over" and became "over-reliant" on it. In many cases, the over-reliance and misuse of Roundup is framed in a way that portrays the technology itself (glyphosate and Roundup Ready GE crops) as so effective that farmers would have been irrational to do anything other than what they did. 
Growers used the same game plan again and again over a period of 15 years because they had no other weed-control option that they saw as offering them comparable value in terms of farm profitability and flexibility in operations (Jan Stautz, 2013, GMO Answers).

Resistance of insects and weed resistance and plant pathogens for that matter has been around forever. It's the misuse of these technologies that creates the resistance. So a cost is, if you think back when Roundup Ready soybeans were introduced in the late 90's, it's almost like, I hate to say it this way, but they worked way too well. And farmers said oh, this is just perfect technology. .... And so farmers said I've got my solutions, and they just overused the technology (Harry; Leader Biotech Regulations, Biotech Company (GMO 112)).

The view that farmers themselves are responsible for the problem that now besets them is pervasive. The USDA also argues that "sole reliance" on glyphosate by growers, together with "a reduction in the diversity of weed management practices", are the key reasons for the evolution of glyphosate resistance in weeds (Fernandez-Cornejo and Osteen 2015:2; 27). There is little attribution of responsibility to the actors who sold or regulated glyphosate and Roundup Ready seeds, that is, biotech companies, seed and chemical companies, and government regulators.

While farmers may have played a central role in the spread of glyphosate resistant weeds, it seems disingenuous to ignore the role that other stakeholders have played, especially Monsanto. Many natural scientists and environmentalists warned that the "wide-spread application of glyphosate on millions of hectares" due to the adoption of GE crops would place "enormous selection pressure ... on weed communities" and therefore the assumption that weeds would not develop resistance was naïve (Owen 2010: 160). Even DuPont weed scientist, Jerry Green, told 
Science magazine, "From a biological perspective this is inevitable" (Service 2007: 1115). In fact, the first glyphosate resistant weed was discovered in Australia in 1996, the same year that glyphosate-resistant GE crops were commercially released (Service 2007). Yet, even in the wake of growing evidence that resistance was occurring, Monsanto continued to argue that if the herbicide was 'used correctly' it was doubtful that plants would be able to overcome their vulnerability to glyphosate and weed resistance was unlikely to occur (Nature 2015). For example, as late as 2007 the company published a paper ${ }^{7}$ arguing that regardless of on-farm practices, weed resistance to glyphosate was very low. ${ }^{8}$ Without acknowledging any responsibility, the company now recommends "that farmers use a mix of chemical products and ploughing" (Gilbert, Nature, 2013:25).

Proponents of GE look to the market and view the development of new chemicals and new GE products as critical to providing farmers with new tools to deal with the problem of weed resistance. If there is one major criticism of biotech, seed and chemical companies expressed by GE proponents, it is that they have been negligent in developing new chemicals or GE crops and are now playing 'catch-up.' Yet, a major problem had been that Roundup was “so cheap and so effective" that it made it difficult for other companies to compete (Ezra, Agronomic Researcher, Farm Organization (GMO 129)).

[I]ndustry has to be out there pitching and we have to be developing new products. ...a lot of the crop protection companies have a very short view of things and stopped paying attention to developing new pesticides for corn and soybeans, where we should have been

\footnotetext{
${ }^{7}$ Wilson, RG et.al, 2007 Weed Technology 21, 900-909.

${ }^{8}$ Scientists were critical of the study because it used "plots so small that the chances of resistance developing were very low, no matter what the practice" (Gilbert, Nature, 2013:25).
} 
working hard at it all along (Harry, Leader Biotech Regulations, Biotech Company (GMO 112)).

Glyphosate was the best herbicide to use with the Roundup trait, but now weeds are starting to develop resistance to the herbicide... so companies have to ask themselves what's next? So now instead of one gene, they are going to have to stack a couple. For example, a Roundup Ready gene with a LibertyLink gene (Andrew, Director, Production Systems, Farm Organization (GMO 101)).

Nevertheless, proponents are optimistic that new biotechnologies, such as Enlist Duo and Roundup Ready Xtend (Monsanto's new herbicide released to combat GR weeds), are being developed and gaining regulatory approval, which will provide farmers with additional tools to deal with the problem of glyphosate resistance and "more options for effective weed control than they've had in the entire history of agriculture" (Jan Stautz, 2013, GMO Answers). In late 2016, Monsanto's Roundup Ready 2Xtend soybeans is in the final stages of EPA review, and has already been approved for import to China and the Europe Union.

At the same time, proponents of GE argue that individual farmers need to learn the lessons from the rise of glyphosate resistant weeds and change their behavior, including integrating Best Management Practices. On the pro-GE website, GMO Answers, Cornell University plant pathologist, Peter Davies, wrote that the answers to resistant weeds are "good farming practices, namely crop rotation, changing herbicide used, and incorporating a small percentage of non-GM seed in insect-resistant crops" (Davies, 2014). A fact sheet disseminated by the Weed Society for America and advertised via a link on the GMO Answers website suggests integrated weed management strategies including tillage, cultivation, hand hoeing and seed capture (2014). GMO112 believes that, while insufficient on their own, improvements in farmer education to 
make them aware of the problem do have to be made. He also suggests that IPM (integrated pest management) should be more widely used throughout all of agriculture. One participant warned that if farmers did not change their on-farm practices by rotating more than one herbicide, then the problem of resistance would keep reoccurring.

If [farmers] just start using Roundup Ready Xtend as they used Roundup in the past, you're just gonna have resistance build up to $2-4 \mathrm{D}$ or dicamba that much more quickly and then you're gonna be in the same situation (Ezra, Agronomic Researcher, Farm Organization (GMO 129)).

Proponents of GE did not think that greater regulatory oversight would be effective in minimizing the problem of weed resistance in the future. Harry, a Leader of Biotech Regulations for a Biotech Company (GMO 112) said: “I don’t think laws and regulation can help. I think there's going to be too many unintended consequences. I just have a hard time believing that that would work for most farmers, they're so independent. Every farmer says 'well that might work for my neighbor then but it's not going to work for me, so I'm not going to follow that rule.' Even by threat of some kind of penalty.” In fact, for most participants, government regulations were the key obstacle to getting new (and old) pesticides $^{9}$ and biotech products into the hands of farmers to address the problem of resistance.

[T]he government's just delaying a lot of solutions that the farmers have. So where it used to take a couple of years to go through the EPA and the different groups, governmental approvals, now it's five, six plus years sometimes, and so you have a company that it could take a dozen years to get a product to market and if you think about how many millions and millions of dollars that takes, and in that whole time you can't sell it, and in

\footnotetext{
${ }^{9}$ To be clear, regulatory approval here involves approving old chemicals, such as $2,4 \mathrm{D}$, for new uses.
} 
the end it may get scratched. So you have all these products that you're trying to get to market, it gets really expensive, and so the government I see as one of the biggest problems (Ezra, Agronomic Researcher, Farm Organization (GMO 129)).

In short, then, for GE proponents, the focus remains on individual farmer practices and behaviors. While weed resistance is claimed to be a natural occurrence, farmers are viewed as primarily responsible for intensifying the problem of glyphosate resistance. In naturalizing and scaling down the problem, the solution from this perspective is to help farmers fight this problem by making new private-sector technologies available while encouraging them to change their onfarm practices. Government regulations do not work and in fact, increased regulatory oversight has slowed the development of biotech and chemical alternatives for farmers, according to GE proponents.

\section{Scaling up the Problem: Superweeds and the Transgene-Facilitated Herbicide Treadmill}

GE critics have embraced the term 'superweeds,' especially in their websites and other materials aimed at the public. In 2013, Just Label It, an organization committed to GE labeling wrote: "Attack of superweeds - a GE crop problem that must be solved: As farmers began to use more and more Roundup, genes for glyphosate resistance began to spread... and the superweeds crisis was born." These critics use the term to capture their view that these weeds are not the norm and present new challenges for society. For example, for many farmers the traditional means for eradicating weeds, such as pesticides or plowing, are no longer effective.

I forget what that weed is...that really, really nasty weed that is so bad that the only way they can get it out of the cotton field...[is] by taking huge machetes and cutting them down. Nothing can get through them. They can't figure out what the heck to spray on 
them to get rid of them. So now we've got poor people... in these fields cutting down these horrendous weeds (Megan, Marketing Executive, Organic Company (GMO114)).

I think most weed scientists bristle at the term and I think it is ridiculous to get upset about it. On a biology side of things they are not super, but weed is a subjective term anyway. If you have a cropping system that is based totally on herbicides, a weed that is immune to herbicides is pretty super in my view (Ken, University Agronomic Researcher/Educator (GMO 126)).

In their description of the development and spread of superweeds, GE critics tend to scale up responsibility for the problem. Farmers are important players who over-used glyphosate and bear some responsibility in the creation of superweeds, but the actions of farmers are typically contextualized in recognition that the agricultural system provides few, if any, economically viable alternatives for commodity farmers to the widespread use of herbicides. Many critics suggested that overuse of glyphosate was an essential component of the commodity agriculture system and its unsustainability. In some cases, farmers are portrayed more as unwitting victims of an agricultural system that necessitates and encourages chemicals. For example, on their website the Environmental Working Group wrote: "Farmers desperately spray even more weed killer, repeating the cycle until they've created nearly indestructible weedy monsters" (Kustin, 2014a). In other cases, similar to proponents of GE, both GE critics and agricultural scientists agree that in a context whereby glyphosate and Roundup was cheap, easy to apply, and worked exceptionally well at killing weeds, there were few incentives for farmers to do anything differently.

If farmers wanted to not only use glyphosate, what were their options? There were other herbicides, but they would cost more, they would have the potential for crop injury, they 
wouldn't have the flexibility in timing. So even though we knew it was not sustainable, you fully understood why farmers did it (Ken, University Agronomic Researcher/Educator (GMO 126)).

I mean it's economics. It's hard to spend money to address a problem you don't have. If I can control those weeds now, why do I want to do something different and spend more money in anticipation of a problem? This system was easy, it worked. So we used it until it died (Chad, University Agronomic Researcher/Educator (GMO 127)).

However, in contrast to proponents, GE critics, together with some weed scientists and extension agents, sought to assign more blame for the problem on ag-biotech companies, especially Monsanto, for the rapid spread of weeds. On their website, the Environmental Working Group argues that the “agrichemical industry's promise that genetically engineered crops would reduce pesticide use has been broken...Monsanto's Roundup requires ever more glyphosate in order to kill the 'superweeds' that evolved as a result of overuse of Roundup" (Kustin, 2014b). A major criticism, especially from university agronomists and extension agents, and articulated in our interviews, was that farmers were told repeatedly by Roundup developers and vendors that resistance could not happen.

[W] were told over and over and over by Monsanto and some of the weed scientists that there's no glyphosate resistant weeds in the world (Chad, University agronomic researcher/educator (GMO 127)).

I think that the industry bears a good bit more responsibility for this problem than is often acknowledged in discussions of it. Monsanto had placed ads in farm press publications in 2003-2004 and in these ads they were telling farmers they could rely completely on glyphosate to control weeds with Roundup Ready crops, and went so far as to say that 
there was no benefit to rotating glyphosate. And specifically saying you won't get resistant weeds by relying completely on glyphosate ${ }^{10}$ (Sam, Policy Analyst, Food and Environmental Organization (GMO128)).

Critics also attributed the spread of glyphosate resistance to inadequate regulatory oversight of both GE crops and pesticides. They argued that the USDA and EPA ignored many of the concerns that were raised by scientists and environmental organizations and subsequently failed to adequately pre-empt environmental problems, such as weed resistance. As stated by the GMO critics:

All of the issues about weed resistance were raised at the very beginning [when Roundup was first introduced], we were all assured that it was going to be managed and that [weed resistance] was not going to happen. Here we are now and we're been told the same thing about 2,4-D (Christopher, Vice President, Environmental Organization (GMO 111)).

[Weed resistance] was a concern from the beginning and we felt and have reiterated to countless federal agencies, particularly the USDA as well as the EPA. But in its role as lead regulator the USDA was failing to adequately assess the environmental impacts that would arise from resistant weed populations (Nick, Director Government Relations, Food and Environmental Organization (GMO 102)).

Some GE critics have sought to directly link the problem of superweeds with GE crops in an effort to mobilize public opposition to GE or build support for GE labeling. This is evident from

\footnotetext{
${ }^{10}$ For more information on Monsanto's misleading advertising claims regarding glyphosate, please refer to Gilbert (2013) as well as Bob Hartzler's (Extension Weed Management Specialist, Department of Agronomy, Iowa State University) websites: "Herbicide Ad 'Hall of Shame"” (http://www.weeds.iastate.edu/weednews/adhallofshame.htm) and "What, Me Worry?" (http://www.weeds.iastate.edu/mgmt/2003/monad.shtml).
} 
the quote above from the website of the organization Just Label It. However, our interviews revealed that most critics stop short of blaming GE crops exclusively for the problem of superweeds. Participants believed that the development of GE crops contributed to the problem because it allowed for the intensive and extensive use of glyphosate. However, critics, together with university agronomists and extension agents, sought to contextualize the problem of superweeds within a broader critique of productionist agriculture; a system built on and dependent upon the intensive use of pesticides. From this perspective, glyphosate resistant weeds are neither natural nor inevitable but rather a systemic problem that was both foreseen and avoidable.

Really the fact that GMOs really reinforce these big monoculture systems is really part of the problem and the fact they reinforced corporate control of the system is a big problem. ...I think for us we put it in the bigger picture, it's not just GMOs. Like you can switch away from GMOs and still be using a lot of pesticides and atrazine and whatever (Paul, Vice President, Agriculture and Environmental Organization (GMO 116)).

In general, you could say that chemical agriculture is responsible for [glyphosate resistant weeds]. ...I think monoculture is another aspect of it. It allows a particular distinct type of agriculture to be repeated season after season after season on particular plots of land. It also encourages the development of those superweeds. So, monoculture and chemical agriculture combined (Frank, Director Research, Food and Environmental Organization (GMO 113)).

Weed resistance then is tied to a particular form of agricultural production that is based on monocultural production of commodity corn and soybeans in the Midwest and cotton in the South dependent on chemical inputs. Critics used the concept of the 'treadmill' or 'chemical 
treadmill' to highlight the relationship they see between pesticides and industrial agriculture (McAfee, 2003). GE is viewed as a technology that helps to maintain this system of agriculture, what Mortensen et.al, (2012) call the "transgene-facilitated herbicide treadmill." For these critics, regulatory approval of new GE crops, such as Enlist Duo, which rely on older herbicides, such as 2-4 D and dicamba, will simply perpetuate the "pesticide arms race" and "chemical treadmill” (Mitchell, 2014; Batcha, 2014).

People ... smarter than us have been warning for a long time that this is what is going to happen with the chemical treadmill when you push one chemical this hard, when Roundup becomes so ubiquitous. Guess what's going to happen to the usefulness of Roundup? And now here we are and we're in the making for 2,4-D ready, dicamba ready, and nobody seems to argue that these are tougher, more worrisome chemicals than Roundup and here we are way earlier than anyone said we would be. Good going! It's kind of escalating to those other chemicals (Laurel, Director, Food and Environmental Organization (GMO 103)).

I hate saying this but with the chemistry and the systems we have in place now [farmers are] going to have to use more pesticides... we don't have a better answer at this point because our whole system is set up for corn and soybeans. [To deal with weed resistance] we are telling guys to put more, more, more, more on (Chad, University Agronomic Researcher/Educator (GMO 127)).

Several participants who work with farmers expressed concern that farmers had embraced the notion of the treadmill, trusting that the biotech industry would be able to solve the problem of glyphosate resistance through the development of new biotech products or chemistries. Dentzman et al (2016) also found from their focus group research that many farmers in the 
Midwest and in the South remain techno-optimists, certain that a new product will emerge to solve glyphosate resistance. Our interviewees expressed concern that these new GE products do not offer a long term, sustainable solution to the problem of weed resistance.

Sadly, I still don't think [farmers] get it...a lot of farmers' attitude is companies or universities are just gonna come up with the next solution and I'm just waiting for that. And so the next thing coming on the market for herbicides is your GMO traits for dicamba and 2-4D. ...And so a lot of farmers are thinking 'Yeah, great, we've got new tools' but they're not new chemistries. .... It's not something new that the weeds haven't seen before (Ezra, Agronomic Researcher, Farm Organization (GMO 129)).

A lot of [farmers] think that the next big thing is dicamba-resistant soybeans, they think that's going to come to the rescue. I don't think they've quite come to grips with the fact that we used dicamba for thirty years or whatever. ... And their perception is that it's going to come in and save the day. That's not going to happen (Chad, University Agronomic Researcher/Educator (GMO 127)).

Within this context of the treadmill, many — but not all— anti-GE critics argue that more regulatory oversight of GE crops is necessary. One argument in favor of increased regulatory oversight is that the approval of Enlist Duo and Roundup Xtend will lead to significant increases in 2,4-D and dicamba applications. Both pesticides are widely viewed as more toxic than glyphosate with many potential health and safety effects for humans and the environment still unknown. GMO108, a neutral party in regards to GE, agreed that her organization would be supportive of stricter oversight because it would assure people that the products truly are safe for humans, animals, and the environment. Part of the call for stricter regulatory oversight was 
linked to a perception that farmers had failed to demonstrate that they would voluntarily follow best management practices in using pesticides.

We need to make them do it. We wrote language in for Bt corn: "you will do this." You make them do it. You make them be accountable. I am not a big regulation guy but sometimes enough is enough. We have proven that we are really bad at using our tools that work and sustaining them. But if we abuse them we will lose them (Chad, University Agronomic Researcher/Educator (GMO 127)).

However, not all participants who were critical of the treadmill were in favor of regulation. I am all for regulation but I don't see how you can regulate resistance management just because it is such a site specific situation and I hate to think that a farmer would have to get a quote "prescription" to do something. Because that obviously has not worked with antibiotics since antibiotics needs a prescription (Ken, University Agronomic Researcher/Educator (GMO 126)).

Since some opponents of GE view monoculture farming —not GE—as the fundamental problem, they tend to argue that any serious effort to address herbicide resistant weeds will require a shift towards a more sustainable, agroecological system of farming that is less dependent on chemicals. Bill Freese, science policy analyst at the Center for Food Safety stated that the "only way out of this chemical arms race with weeds is a major commitment to nonchemical weed management techniques" (Center for Food Safety, 2012). Frank, a Director of Research for a Food and Environmental Organization, explained that moving towards a system that has a "deeper appreciation of the role of soil and diversity and sustainability" would be the best way to deal with environmental problems such as herbicide resistance. Another critic noted "The monoculture system is incredibly harmful.... For us it's not a switch from GE, for us it will 
be a switch to different agro-ecological systems that need to be more diverse (Paul, Vice President, Agriculture and Environmental Organization).

In sum, some GE critics frame the problem of superweeds as related to a broader suite of problems linked to the dominant monocultural system in conventional agriculture. By invoking terms like superweeds and pesticide treadmill, these problems are scaled up, that is framed as systemic and potentially quite dangerous for the agricultural system if left unchecked. These framings lead to solutions then that are also broader, more systemic, and linked to changes in the agricultural paradigm to support more sustainable production systems — calls for more regulatory oversight and for overhauls of the conventional agriculture system's reliance on pesticides.

\section{Discussion and Conclusion}

In the current context, farmers are compelled to implement more environmentally harmful onfarm practices to kill resistant weeds, such as increased tillage and the use of more toxic herbicides. This development undermines a key narrative justifying GE: that GE crops are necessary and valuable because they provide economic benefits to farmers and environmental benefits to society. Social movement opposition to GE and public debate over glyphosate as a potential human carcinogen have also been instrumental in undermining the justifications for GE agriculture.

Within this context, our study found broad agreement among both proponents and opponents of GE - from farm and biotech industry groups, consumer and environmental organizations, to agronomists and government regulators - that glyphosate resistant weeds are a significant problem that must be addressed. This is largely where the agreement ends, however. Important differences between these actors are demonstrated in terms of how the problem is framed, at what scale, and who or what is responsible. How glyphosate resistant weeds themselves get 
defined, as superweeds or survivors, and whether their spread is framed as the result of individual negligence or a failed agrifood production system, has direct implications in terms of the kinds of governance and regulatory responses that are advocated for resolving the problem.

Proponents of GE crops draw on discourses and frames of scale and neoliberalism to both naturalize the problem of glyphosate resistance and scale down how the problem should be perceived and addressed. Here, weed resistance is a naturally occurring phenomenon across all agricultural systems. However, the 'overuse' of Roundup Ready by individual farmers led to the rapid and extensive spread of glyphosate resistance while institutional or structural agents related to government, industry or the agrifood system are largely absolved of any responsibility. From this perspective, the solution is to develop new market based techno-scientific strategies, especially new biotech crops. At the same time, there is also agreement that farmers need to be educated on how to change their attitudes, behavior and practices to avoid reproducing this problem in the future and to demonstrate better "glyphosate stewardship" (Bonny, 2016). The role of government is to aid this process by loosening rather than tightening government oversight that can facilitate regulatory approval of new biotech crops and pesticides for farmers.

In contrast, critics of GE crops and pesticides have scaled up the problem of superweeds and emphasize that this is a human-induced, systemic problem related to the dominant commodity agricultural paradigm rather than a natural phenomenon. The fundamental cause of superweeds is not the actions of individual farmers but rather an agro-industrial model of agriculture that is inherently dependent on the over-reliance and overuse of chemical inputs. Roundup Ready GE crops reliant on glyphosate deepened this dependence. With government oversight of Roundup Ready's adoption largely verboten, the widespread adoption of this technology placed unprecedented pressure on weeds, creating an ideal environment under which resistant weeds 
could quickly develop. With recent regulatory approval of Enlist Duo, the pesticide treadmill has evolved into the transgene-facilitated herbicide treadmill compelling farmers to adopt the next new chemically-dependent biotech product. From this perspective, superweeds are a symptom of both a failed model of agriculture and a failed system of regulatory oversight. In general, most critics of GE argue that the long-term solution must be a systems approach, that is, a sustainable agro-ecological model. In the meantime, however, GE opponents also argue the government should impose binding federal regulations that can address the direct and indirect harms from GE crops, including herbicide-resistant weeds and the increased use of herbicides.

In sum, we show that the politics of scale is central to the contestation over the problem of, and solution to, glyphosate resistant weeds. As Harrison (2006) illustrates, when environmental problems are 'scaled up' to show how they impact a larger constituency, such as linking the effects of pesticide drift on farm workers to a larger problem of air pollution, there are greater possibilities for pushing for government intervention and regulation. This is especially important for addressing cases of environmental injustice, where environmental problems intersect with, and are exacerbated by, issues of inequality (Harrison, 2006; Harrison 2011; Kurtz, 2003). In our case, scale has been powerfully used by both sides as a framing device to explain who is responsible for the problem, how the problem should be addressed and by whom. Perhaps the recent release of evidence of the link between glyphosate and cancer will bring increased attention to the health and environmental impacts of the pesticide treadmill that is fundamental to GE agriculture. Moreover, increased social movement mobilization around GE agriculture that led to passage of federal GMO labeling legislation in the US in 2016 may portend a reassessment of social and environmental implications of GE agriculture. Linking the problem of glyphosate resistant weeds to increasing consumer concerns over impacts of pesticides and GE in food may 
coalesce a larger public to demand more effective regulatory oversight for the biotech industry overall. 


\section{References}

Abrams, Lindsay 2015. “EPA takes on superweeds: New restrictions target Monsanto’s Roundup herbicide" Salon. April 1. Accessed October 22, 2015.

http://www.salon.com/2015/04/01/epa_takes_on_superweeds_new_restrictions_target_monsa $\underline{\text { ntos_roundup_herbicide/ }}$

APHIS. (Animal and Plant Health Inspection Service). 2014. "APHIS Recommendations for Best Management Practices for Authorized Field Trials of Regulated Herbicide-Resistant Crops.” Accessed October 24, 2015.

https://www.aphis.usda.gov/brs/aphisdocs/aphis_bmp_recs_hr_crops.pdf.

Batcha, V. 2014. "Dangerous Weed Killers are Helping to Spread "Superweeds.” Just Label It, January 3. Accessed October 22, 2015. http://www.justlabelit.org/dangerous-weed-killers-arehelping-to-spread-superweeds/.

Benbrook, C. 2012. "Impacts of Genetically Engineered Crops on Pesticide Use in the U.S. - the First Sixteen Years.” Environmental Sciences Europe 24: 24.

Binimelis, R., W. Pengue, and I. Monterroso. 2009. “"Transgenic Treadmill”: Responses to the Emergence and Spread of Glyphosate-resistant Johnsongrass in Argentina.” Geoforum 40: $623-633$.

Bonn, Dorothy. 2005. Roundup Revelation. Environmental Health Perspectives 113(6): A403-4.

Bonny, S., 2016. Genetically modified herbicide-tolerant crops, weeds, and herbicides: overview and impact. Environmental management, 57(1), pp.31-48.

Callahan, P. 2015. EPA Tosses Aside safety data, says Dow pesticide for GMOs won’t harm people. Chicago Tribune. December 9. Accessed October 14, 2016. 
http://www.chicagotribune.com/news/watchdog/ct-gmo-crops-pesticide-resistance-met20151203-story.html

Callahan, P. 2016. Court Clears the Way for Revival of Worrisome Weedkiller. Chicago Tribune January 28. Accessed October 14, 2016. http://www.chicagotribune.com/news/watchdog/ctdow-enlist-duo-court-ruling-20160127-story.html

Campbell, J. L., and O. K. Pedersen. 2001. "Introduction: The rise of Neoliberalism and Institutional Analysis.” In J. L. Campbell and O. K. Pedersen (Eds.) The Rise of Neoliberalism and Institutional Analysis, 1-23. Princeton, New Jersey: Princeton University Press.

Center for Food Safety. 2012. "National Weed Summit Tackles Epidemic of Herbicide-Resistant 'Superweeds."” Accessed October 24, 2015. http://www.centerforfoodsafety.org/video/2519/cfs-videos/press-releases/708/national-weedsummit-tackles-epidemic-of-herbicide-resistant-superweeds\#.

Cox, Caroline and Michael Surgan. 2006. Unidentified Inert Ingredients in Pesticides: Implications for Human and Environmental Health. Environmental Health Perspectives 114(12): 1803-06.

CSPI (Center for Science in the Public Interest). 2012. Straight Talk on Genetically Engineered Foods. Washington, DC: CSPI. Accessed October 22, 2015. http://cspinet.org/new/pdf/biotech-faq.pdf Davies, P. 2014. "In support of GMO Crops." GMO Answers, March 12. Accessed May 13, 2015. https://gmoanswers.com/studies/support-gmo-crops. 
Dentzman, K., Gunderson, R. and Jussaume, R., 2016. Techno-optimism as a barrier to overcoming herbicide resistance: Comparing farmer perceptions of the future potential of herbicides. Journal of Rural Studies, 48, pp.22-32.

Dodrill, T. 2015. Superweeds are Winning the Battle Against Farmers.” Inquisitr, Jan. 4. Accessed October 21, 2015. http://www.inquisitr.com/1726952/superweeds-are-winning-the-battleagainst-farmers/.

Eller, D. 2014. “'Superweeds”" Choke Farms.” Des Moines Register, June 23. Accessed March 3, 2015. http://www.desmoinesregister.com/story/money/agriculture/2014/06/22/superweedschoke-farms/11231231/.

EPA (U.S. Environmental Protection Agency) 2014. "Registration of Enlist Duo.” November 17, 2014. Accessed October 22, 2015. http://www2.epa.gov/ingredients-used-pesticideproducts/registration-enlist-duo\#decision.

Ervin, D. and R. Jussaume. 2014. "Integrating Social Science into Managing Herbicide-Resistant Weeds and Associated Environmental Impacts." Weed Science 62(2):403-14.

Fischer, K., Ekener-Petersen, E., Rydhmer, L. and Björnberg, K.E., 2009. Social Impacts of GM Crops in Agriculture: A Systematic Literature Review. Sustainability 2015, 7, 8598-8620. Pak. J. Agric. Res, 22, pp.73-85.

FDA (U.S. Department of Health and Human Services-Food and Drug Administration). (1992). Statement of Policy: Foods Derived from New Plant Varieties. Federal Register 57:2298423005.

Fernandez-Cornejo, J., S. Wechsler, M. Livingston, and L. Mitchell. 2014. Genetically Engineered Crops in the United States. ERR-162 U.S. Department of Agriculture, Economic Research Service. Accessed October 21, 2015. http://www.ers.usda.gov/media/1282246/err162.pdf. 
Fernandez-Cornejo, J. and C. Osteen. 2015. "Managing Glyphosate Resistance May Sustain Its Efficacy and Increase Long-Term Returns to Corn and Soybean Production.” U.S. Department of Agriculture, Economic Research Service, May 4. Accessed October 22, 2015. http://ers.usda.gov/amber-waves/2015-may/managing-glyphosate-resistance-may-sustain-itsefficacy-and-increase-long-term-returns-to-corn-and-soybean-production.aspx\#.Vik_$\underline{\mathrm{CuJ} 26 \mathrm{Q}}$.

Gilbert, N. 2013. “Case studies: A hard look at GM crops.” Nature. 497 (7447): 24-26.

Gillam, C. 2013. "Genetically Modified Crops Have Led To Pesticide Increase, Study Finds." Huffington Post, June 10. Accessed October 22, 2015. http://www.huffingtonpost.com/2012/10/02/genetically-modified-cropspesticides_n_1931020.html.

Gillam, C. 2015. "EPA will Require Weed-resistance Restrictions on Glyphosate Herbicide." Reuters, March 31. Accessed October 24, 2015. http://www.reuters.com/article/2015/03/31/us-monsanto-herbicide-weedsidUSKBNOMR2JT20150331.

Harrison, J. L. 2006. “Accidents' and Invisibilities: Scaled Discourse and the Naturalization of Regulatory Neglect in California's Pesticide Drift Conflict." Political Geography 25: 506-529 Johnson, Bill, Bryan Young, Travis Legleiter. 2015. Adjuvants alone won't solve glyphosate resistance. Farm Journal's AgPro. July 20. http://www.agprofessional.com/news/adjuvantsalone-won\%E2\%80\%99t-solve-glyphosate-resistance. Accessed December 27, 2016. Just Label It. 2013. "Attack of the Superweeds - a GE Crop Problem that Must be Solved." Just Label It, July 2. Accessed October 24, 2015. http://www.justlabelit.org/attack-of-thesuperweeds-a-ge-crop-problem-that-must-be-solved/. 
Kinchy A. J., D. L. Kleinman, and R. Autry. 2008. “Against Free Markets, Against Science?

Regulating the Socio-Economic Effects of Biotechnology.” Rural Sociology 73 (2): 147-179.

Kleinman, D. L. and A. J. Kinchy. 2003. "Boundaries in Science Policy.” The Sociological Quarterly 44(4):577-95.

Koba, M. 2014.“'Superweeds’ Sprout Farmland Controversy over GMOs.” NBC News, Sept. 30. Accessed October 21, 2015. http://www.nbcnews.com/business/economy/superweeds-sproutfarmland-controversy-over-gmos-n214996.

Koebler, J. 2012. “Herbicide-Resistant 'Super Weeds' Increasingly Plaguing Farmers.” U.S. News, Oct. 19. Accessed October 21, 2015. http://www.usnews.com/news/articles/2012/10/19/herbicide-resistant-super-weedsincreasingly-plaguing-farmers.

Krimsky, S. and J. Gruber. 2014 "Introduction. The science and regulation behind the GMO deception.” In S. Krimsky and J. Gruber (Eds.) The GMO Deception, (xviiii-xxix). Skyhorse Publishing: New York, NY.

Kurtz, H. E. 2003. “Scale Frames and Counter-scale Frames: Constructing the Problem of Environmental Injustice. Political Geography 22: 887-916.

Kustin, M. 2014a. “New Herbicide Would Bring Hollywood's 'Terminator’ to Life.” Environmental Working Group, Aug. 18. Accessed March 3, 2015. http://www.ewg.org/agmag/2014/08/new-herbicide-would-bring-movies-terminator-life. Kustin, M. 2014b. “The Agrichemical Industry’s Broken Promise.” Environmental Working Group, Sept. 15. Accessed March 3, 2015. http://www.ewg.org/agmag/2014/09/agrichemicalindustry-s-broken-promise. 
Lieshout, M. V., A. Dewulf, N. Aarts, and C. Termeer. 2014. "The Power to Frame the Scale? Analysing Scalar Politics over, in and of a Deliberative Governance Process." Journal of Environmental Policy \& Planning 1-24.

McAfee, K. 2003. "Neoliberalism on the molecular scale. Economic and genetic reductionism in biotechnology battles.” Geoforum 34(2): 203-219

McCarthy, J. and S. Prudham. 2004. "Neoliberal Nature and the Nature of Neoliberalism." Geoforum 35: 275-283

Meersman, T. 2014 “'Superweeds' Emerge to Challenge Farmers.” Star Tribune, Aug. 24. Accessed October 21, 2015. http://www.startribune.com/aug-2-herbicide-resistantsuperweeds-emerge-to-challenge-farmers/269632941/.

Mitchell, E. 2014. "Syngenta Correctly Predicts Superweeds Infestation: Jolly Well Done!" Food and Water Watch, Jan. 6. Accessed March 3, 2015.

http://www.foodandwaterwatch.org/blogs/syngenta-correctly-predicts-superweedsinfestation-jolly-well-done/.

Molla, R. 2014. "The Rise of Super Weed Around the World.” Wall Street Journal, Jan. 22. Accessed October 21, 2015. http://blogs.wsj.com/numbers/the-rise-of-the-super-weed-aroundthe-world-1458/.

Mortensen, D. A., J. F. Egan, B. D. Maxwell, M. R. Ryan, and R. G. Smith. 2012. "Navigating a Critical Juncture for Sustainable Weed Management.” BioScience 62 (1): 75-84.

NAS (National Academy of Sciences). 2010. Impact of Genetically Engineered Crops on Farm Sustainability in the United States (2010) National Academies of Science.

NAS (National Academy of Sciences). 2016. Genetically Engineered Crops: Experiences and Prospects. Washington, DC: The National Academies Press. 
Neuman, W. and A. Pollack. 2010. "Farmers Cope with Roundup-resistant Weeds." The New York Times, May 3. Accessed March 21, 2015. http://www.nytimes.com/2010/05/04/business/energyenvironment/04weed.html?pagewanted=all.

NRC (National Research Council). 2010. The Impact of Genetically Engineered Crops on Farm Sustainability in the United States. Washington, DC: National Academies Press.

Owen, M. D. 2010. “Herbicide resistance.” In F. Krempkrn snf V. Jung (eds). Genetic modification of plants (pp. 159-176). Springer: Berlin Heidelberg.

Owen, M. and IA Zelaya 2005. "Herbicide-resistant Crops and Weed Resistance to Herbicides. Pest Management Science 61 (3): 301-11.

Philpott, T. 2011. "Wait, Did the USDA Just Deregulate All New Genetically Modified Crops?" Mother Jones, July 8. Accessed October 22, 2015. http://www.motherjones.com/environment/2011/07/usda-deregulate-roundup-gmo-tomphilpott.

Roff, R. J. 2008. "Preempting to Nothing: Neoliberalism and the Fight to De/Re-regulate Agricultural Biotechnology." Geoforum 39: 1423-1438

Roff, R. J. 2007. "Shopping for Change? Neoliberalizing Activism and the Limits to Eating NonGMO.” Agriculture and Human Values 24(4):511-22.

Service, R. 2007. “A Growing Threat Down on the Farm.” Science 316 (5828): 1114-1117.

Service, R. 2013. "What Happens When Weed Killers Stop Killing?" Science 341 (6152): 1329.

Stautz, J. 2013. “Experts.” GMO Answers, Dec. 19. Accessed October 22, 2015. https://gmoanswers.com/experts/jane-stautz. 
Stone, G. D. 2010. "The Anthropology of Genetically Modified Crops." Annual Review of Anthropology 39: 381-400

Sumberg, J., J. Thompson, and P. Woodhouse. 2014. "Political Agronomy." In P. Thompson and D. Kaplan (Eds.) Encyclopedia of Food and Agricultural Ethics, 1-8. Springer: New York, NY.

USDA (United States Department of Agriculture). 2015a. (2015, Jan. 20). “Noncompliance History.” January 20, 2015. Accessed October 22, 2015.

https://www.aphis.usda.gov/wps/portal/aphis/ourfocus/biotechnology/sa_compliance_and_ins pections/!ut/p/a1/tVJNU8IwFPwresCLU5K20BZnHKf4AeVDHZSR9tJJQ9rGKUIIUIF_vSlc $\underline{\text { dEYRD- }}$

b2kt23efsWJGABEoZeaIE05QxVTZ146ehu6Nh96ESDwXUfRrc3k3t_PHKg0zWAeA9g3D 2MfzkIhx1_AiHsBA6MrvrDK783hTDyDuPDH04If-

M_gQQkmGmhSxAjUVKVYs40YTqtaCaRfGtBhVJeyzTnuFbbKqNcE1wyXvFi9475S1QU MUxSxJYpZUoQ3Hiomv4C0yWIvV5OXAcvrdyzO1bHs7EV-FnPskmGEPaw6_ay3X9cXQL2GfZFrDHkxFIiopn2_3GIcvcoACJJDmRRLZraa5LrcVZC7bgZrNpZ5QVbTOhmZQg icuL9Xmtluj0iw0nSuLz6Np65GJGVF3pk5u72dTc2PBx9p1OyZUGi8_9v0PtFAWSaKXAop $\underline{\text { E9- }}$

iILYhMA_0e7jBsPf9zA6IDI0ef1OglNcJqovJox_iU5RsiR08upsUMgXVqU5Rws9nPEaj6frw $\underline{\text { LXmw3fJ- }}$

Qp0AF0u9XLJAyPjz8AGHahNg!!/?1dmy\&urile=wcm\%3apath\%3a\%2Faphis_content_librar y\%2Fsa_our_focus $\% 2$ Fbiotechnology $\% 2 \mathrm{Fsa}$ compliance_and_inspections $\% 2 \mathrm{Fct}$ _compinsp_ process. 
USDA (United States Department of Agriculture). 2015b. "USDA Announces Final Environmental Impact Statement on Dicamba/Glufosinate Tolerant Cotton and Dicamba Tolerant Soybean.” August 5, 2015. Accessed October 22, 2015. https://www.aphis.usda.gov/wps/portal/aphis/newsroom/news/sa_news/sa_by_date/sa_2014/ ct_12/ct brs_final_eis_cotton_soybeans/!ut/p/a0/04_Sj9CPykssy0xPLMnMz0vMAfGjzOK9 _D2MDJ0MjDzdXUyMDTzdPA2cAtz8jT1dTPULsh0VAbiDHEw!/

van Lieshout, M., A. Dewulf, N. Aarts, and C. Termeer. 2014. "The Power to Frame the Scale? Analysing Scalar Politics over, in and of a Deliberative Governance Process." Journal of Environmental Policy \& Planning 1-24. 


\section{Appendix I}

\begin{tabular}{|c|c|c|c|c|c|}
\hline Code & Pseudonym & Position & Affiliation & Type of Organization & $\begin{array}{l}\text { Stance on } \\
\text { GMOs }\end{array}$ \\
\hline GMO 101 & Andrew & $\begin{array}{l}\text { Director, } \\
\text { Production } \\
\text { Systems }\end{array}$ & NGO & Farm & Proponent \\
\hline GMO 102 & Nick & $\begin{array}{l}\text { Director, Govt } \\
\text { Relations }\end{array}$ & NGO & $\begin{array}{l}\text { Food and } \\
\text { Environment }\end{array}$ & Opponent \\
\hline GMO 103 & Laurel & Director & $\mathrm{NGO}$ & $\begin{array}{l}\text { Food and } \\
\text { Environment }\end{array}$ & Opponent \\
\hline GMO 104 & Brian & $\begin{array}{l}\text { Senior Advisor, } \\
\text { Biotech }\end{array}$ & Government & Biotechnology & Proponent \\
\hline GMO 105 & Devon & Director, Biotech & $\mathrm{NGO}$ & Scientific & Proponent \\
\hline GMO 106 & Betty & $\begin{array}{l}\text { Director, } \\
\text { Communications }\end{array}$ & NGO & $\begin{array}{l}\text { Agriculture and } \\
\text { Environment }\end{array}$ & Proponent \\
\hline GMO 107 & Donald & $\begin{array}{l}\text { VP, Govt } \\
\text { Relations }\end{array}$ & Business & Biotechnology & Proponent \\
\hline GMO 108 & Jessica & $\begin{array}{l}\text { Rep, Govt } \\
\text { Relations }\end{array}$ & NGO & Farm & Proponent \\
\hline GMO 109 & Thomas & $\begin{array}{l}\text { Director, Govt } \\
\text { Relations }\end{array}$ & Business & Biotechnology & Proponent \\
\hline GMO 110 & Steve & Coord, Biotech & Government & Biotechnology & Proponent \\
\hline GMO 111 & Christopher & $\mathrm{VP}$ & $\mathrm{NGO}$ & Environment & Opponent \\
\hline GMO 112 & Harry & $\begin{array}{l}\text { Leader, Biotech } \\
\text { Regulations }\end{array}$ & Business & Biotechnology & Proponent \\
\hline GMO 113 & Frank & $\begin{array}{l}\text { Director, } \\
\text { Research }\end{array}$ & $\mathrm{NGO}$ & $\begin{array}{l}\text { Food and } \\
\text { Environment }\end{array}$ & Opponent \\
\hline GMO 114 & Megan & $\begin{array}{l}\text { Executive, } \\
\text { Marketing }\end{array}$ & Business & Organic & Opponent \\
\hline GMO 115 & Aaron & $\mathrm{CEO}$ & NGO & $\begin{array}{l}\text { Consumer, Food and } \\
\text { Agriculture }\end{array}$ & Proponent \\
\hline GMO 116 & Paul & $\mathrm{VP}$ & NGO & $\begin{array}{l}\text { Agriculture and } \\
\text { Environment }\end{array}$ & Opponent \\
\hline GMO 118 & Heather & $\begin{array}{l}\text { VP, Govt } \\
\text { Relations } \\
\end{array}$ & Business & $\begin{array}{l}\text { Food } \\
\text { Marketing/Education }\end{array}$ & Proponent \\
\hline GMO 119 & Trey & $\mathrm{VP}$ & Business & Food Processor & Proponent \\
\hline GMO 120 & Jillian & $\begin{array}{l}\text { Manager, Public } \\
\text { Relations }\end{array}$ & $\mathrm{NGO}$ & Farm & Proponent \\
\hline GMO 121 & Breanna & $\begin{array}{l}\text { Director, Public } \\
\text { Affairs }\end{array}$ & Business & Organic & Opponent \\
\hline GMO 122 & Marvin & Advisor, Biotech & Government & Biotechnology & Proponent \\
\hline GMO 123 & Jeremy & Exec Director & NGO & Food Policy & Proponent \\
\hline GMO 124 & Ron & Director; farmer & $\mathrm{NGO}$ & Farm & Proponent \\
\hline GMO 125 & Abby & $\begin{array}{l}\text { Director, Govt } \\
\text { Relations }\end{array}$ & $\mathrm{NGO}$ & Farm & Proponent \\
\hline
\end{tabular}




\begin{tabular}{|l|l|l|l|l|l|}
\hline GMO 126 & Ken & $\begin{array}{l}\text { Agronomic } \\
\text { researcher, } \\
\text { educator }\end{array}$ & University & Agricultural scientist & Neutral \\
\hline GMO 127 & Chad & $\begin{array}{l}\text { Agronomic } \\
\text { researcher, } \\
\text { educator }\end{array}$ & University & Agricultural scientist & Neutral \\
\hline GMO 128 & Sam & Analyst, Policy & NGO & $\begin{array}{l}\text { Food and } \\
\text { Environment }\end{array}$ & Opponent \\
\hline GMO 129 & Ezra & $\begin{array}{l}\text { Agronomic } \\
\text { researcher }\end{array}$ & NGO & Farm & Proponent \\
\hline GMO 130 & Riley & VP, Marketing & NGO & Farm & Proponent \\
\hline
\end{tabular}

